\title{
Usia Menarche dari Sudut Pandang Konsumsi Fastfood dan Paparan Media Porno
}

\author{
Ronasari Mahaji Putri ${ }^{1}$, Novitadewi ${ }^{2}$, Neni Maemunah ${ }^{3}$ \\ ${ }^{1-, 3}$ Program Studi Keperawatan Fakultas Ilmu kesehatan Universitas Tribhuwana Tunggadewi \\ Email: putrirona@gmail.com
}

Submitted : 14/01/2020

Accepted: 06/02/2020

Published: 14/03/2020

\begin{abstract}
Many young women experience accelerated menarche age compared to previous years. The high consumption of fast food and exposure to pornographic media is one of the factors that is suspected to influence the age of menarche acceleration. The purpose of this study was to determine the relationship of junk food consumption, media exposure to the age of menarche in young women. The research design uses cross-sectional. The population is all VII grade students of SMPN 26 Malang, with a sample of 90 students obtained by using simple random sample technique. The instrument uses a questionnaire and a checklist sheet. Data analysis using Fisher's exact test. The results of the study revealed that the majority of respondents consumed fast food in the low category of 82 people (91.1\%). Most of the children experienced low exposure to pornographic media, namely 80 people (88.9\%). Statistical tests show that there is no relationship between junk food consumption ( $p$ value $=0.416)$, and exposure to pornographic media $(p$ value $=0.270$ ) with the age of menarche in SMPN 26 Malang students. It is recommended for further researchers to explore the determinants of the acceleration of the age of menarche in adolescent girls, as well as the delay in the age of menarche, further research needs to be done
\end{abstract}

Keywords : fast food, internet, menarche, pornographic

\begin{abstract}
Abstrak
Banyak remaja putri mengalami percepatan usia menarche dibandingkan tahun-tahun sebelumnya. Tingginya konsumsi fastfood dan terpaparnya media porno menjadi salah satu faktor yang diduga mempengaruhi usia percepatan menarche. Tujuan penelitian untuk mengetahui hubungan konsumsi junkfood, paparan media dengan usia menarche pada remaja putri. Desain penelitian menggunakan crossectional. Populasi adalah seluruh siswi kelas VII SMPN 26 Malang, dengan sampel sejumlah 90 siswi diperoleh dengan menggunakan teknik simple random sample. Instrumen menggunakan kuesioner dan lembar checklist. Analisa data menggunakan Fisher"s exact test. Hasil penelitian diketahui sebagian besar responden mengkonsumsi fastfood dalam kategori rendah yakni sebanyak 82 orang $(91,1 \%)$., sebagian besar anak mengalami paparan media porno yang rendah, yakni 80 orang ( $88,9 \%)$. Uji statistik menunjukkan bahwa tidak ada hubungan antara konsumsi junkfood ( pvalue $=0,416$ ), dan paparan media porno (pvalue $=0,270$ ) dengan usia menarche pada siswi SMPN 26 Malang. Direkomendasikan untuk peneliti selanjutnya untuk menggali faktor determinan terjadinya percepatan usia menarche pada remaja putri, demikian juga keterlambatan usia menarche perlu dilakukan penelitian lanjutan.
\end{abstract}

Kata Kunci : , internet, konsumsi siap saji, pornografi; usia menarche

\section{PENDAHULUAN}

Remaja merupakan salah satu tahapan usia yang akan dilalui oleh seseorang. Di masa ini terjadi perubahan fisik maupun psikis.Pubertas merupakan suatu transisi dari masa kanak-kanan menuju dewasa. Saat pubertas, terjadi perkembangan seksual sekunder pada wanita yakni meliputi pertumbuhan payudara dan rambu kemaluan serta menarche (Pulungan AB
2010). Menarche merupakan haid pertama yang muncul dari uterus remaja putri. Terjadinya menarche pada awal remaja dipengaruhi oleh banyak faktor yakni masa tubuh, sosial ekonomi, status gizi, iklim, genetik dan budaya (JW, 2003; S. 2009). Terjadinya menarche menunjukkan bahwa remaja putri sudah mengalami proses menuju kematangan organ reproduksi. 
Berbagai fenomena yang ada menunjukkan bahwa remaja putri mengalami percepatan usia menarche dibandingkan tahun-tahun sebelumnya. Kejadian tersebut tidak hanya dialami oleh remaja di negara Indonesia sendiri, namun ternyata juga melanda pada hampir di seluruh belahan dunia (Nelson WE 1999). Penelitian di India tahun 2008 mengungkapkan bahwa menarche terjadi pada usia 12,62 tahun adalah usia menarche (Purba FS, Sarumpaet SM 2013; Beddu S, Mukarramah S 2015).Usia menarche juga tampak pada Negara berkembang (Ekerbicer HC, Celik M, Kiran H 2007; (Golub MS, etc 2008). Di Indonesia sendiri yakni sebagai negara berkembang di tahun 2010, hasil Riset Kesehatan Dasar mengungkapkan bahwa hampir separoh remaja putri yakni $37,5 \%$ mempunyai usia menarche 13-14 tahun. Gudineau (2010) dalam Wulansari (2012) mengemukakan bahwa terjadi pergeseran usia menarche ke usia yang jauh lebih muda yakni yang disebut menarche dini yaitu kurang dari 11 tahun. A. Susanti (2012) juga menyampaikan bahwa usia menarche remaja putri terjadi pada 12-13 tahun. Data ini menunjukkan adanya penurunan pada usia menarche yakni 0,145 tahun perdekade. Menurut Ayuningtyas R (2013) diusia 9-12 tahun anak merupakan masa usia pubertas, namun jika dirata-rata remaja putri akan mengalami menarche di usia 1213 tahun.

Adanya dugaan bahwa percepatan usia menarche disebabkan oleh peningkatan status gizi remaja. Terjadinya peningkatan status gizi berasal dari konsumsi makanan fastfood. Sependapat dengan Wulansari (2012) yang mengungkapkan bahwa makanan fastfood dan junkfood sangat digemari oleh para remaja, dan konsumsi makanan jenis ini akan menyebabkan remaja putri mengalami peningkatan status gizi. Niken (2010) dalam Wulansari (2012) menerangkan dalam hasil penelitiannya bahwa dari 21 siswa di kelas 5 dan kelas 6 di dua sekolah dasar Surakarta sedikitnya 3 orang telah mengalami menarche di usia
10-11 tahun; tiga siswi diantaranya yang menyukai fastfood mempunyai status gizi yang lebih dibandingkan teman-temannya. Penelitian Schuh, S. M., etc (2019) juga mendukung bahwa usia menarche yang lebih awal dikaitkan dengan status gizi yang melebihi normal. Remaja dengan nutrisi berlebih dapat mempengaruhi terjadinya percepatan usia menarche. Nutrisi mempunyai efek kematangan seksual sehingga akan memunculkan tanda-tanda seks sekunder (Kaplowitz 2008). Tingginya tingkat konsumsi junkfood dikalangan remaja, menyebabkan terjadinya pubertas dini bagi remaja sebagai hasil dari kerja hormone dalam tubuh A. Susanti (2012). Sejalan dengan Surya Anita (2018) mengungkapkan bahwa adanya kaitan antara konsumsi junkfood dengan usia menarche (pvalue=0,021). Menarche sebagai tanda munculnya pubertas pada remaja putri. Terjadinya percepatan usia menarche juga seringkali dihubungkan dengan adanya paparan media.

Dalam sebuah penelitian digambarkan bahwa adanya paparan media massa baik cetak ataupun online menjadi salah satu faktor yang menyebabkan terjadinya penyimpangan perilaku makan pada remaja Nusa, dkk (2012). Menurut Indriyastuti HI (2013) bahwa ada signifikansi antara paparan media dan lingkungan dengan usia menarche pada remaja putri, namun demikian hasilnya tidak konsisten. Penelitian ini juga mengungkapkan bahwa konten informasi global mudah untuk di akses oleh anak dan remaja, dan banyak diantaranya yang mempunyai kebiasan buruk yakni menonton film-film seksual melalui internet atapun gadget yang dimilikinya. Paparan media audio visual yang berisi konten seksual mempercepat menarche pada usia remaja.

Usia menarche yang terlalu dini akan berdampak pada kesehatan remaja. Penelitian Archarya (2009) menunjukkan bahwa usia menarche yang terlalu cepat berhubungan dengan faktor resiko kesehatan yakni seperti lebih peka dalam aktvitas seksual, sehingga meningkatkan 
kehamilan remaja, aborsi dan kematian ibu. Selain itu juga beresiko mengalami gangguan psikologis dan menjadi faktor resiko terjadinya kanket payudara (Archarya 2009; Kaplowitz 2008; Morris, D.H.,etc 2010). Penelitian lain juga mengungkap bahwa menarche dini berkaitan dengan resisten insulin (Zhang, Z., Hu, X., Yang, C., \& Chen (2019). Sedangkan penelitian Karapanou O (2010) mengungkapkan bahwa menarche dini dikaitkan dengan peningkatan resiko peyakit cardiovaskuler serta kanker payudara.

\section{METODE PENELITIAN}

Desain penelitian cross sectional. Penelitian di laksanakan di SMPN 26 Malang pada bulan Oktober 2019. Populasi adalah seluruh siswi kelas VII SMPN 26 Malang, dengan sampel 90 orang yang diambil dengan menggunakan teknik simple random sampling. Variabel independen adalah konsumsi fastfood, dan paparan media. Sedangkan variabel dependent adalah usia menarche. Instrumen menggunakan lembar questioner. Analisa data dengan menggunakan uji Fisher exact.

\section{HASIL DAN PEMBAHASAN}

Berdasarkan Tabel 1 diketahui sebagian besar responden kelas VII SMPN26 Malang berusia 12 tahun yakni 57 orang $(63,3 \%)$; sebagian besar responden mendapatkan informasi tentang menarche yakni 53 orang $(58,9 \%)$; sebagian besar responden mempunyai uang saku Rp 5000Rp10.000 yakni 60 orang(66,7\%); sebagian besar keluarga responden mempunyai pendapatan $>$ Rp 2.500.000,- yakni 55 orang $(61,1 \%)$; sebagian besar responden tidak mengkonsumsi sayur yakni 56 orang $(62,2 \%)$; sebagian besar responden mempunyai 2 kepemilikan media di rumah yakni sebanyak 49 orang $(54,4 \%)$.

Berdasarkan Tabel 2 diketahui bahwa sebagian besar responden mengalami menarche pada usia 11 tahun yakni 34,9\%. Berdasarkan Tabel 3 diketahui sebagian besar anak telah mengalami menarche yakni sebanyak 67 orang (74,4\%). Berdasarkan Tabel 4 diketahui sebagian besar responden mengkonsumsi fastfood dalam kategori rendah yakni sebanyak 82 orang $\quad(91,1 \%)$.

Tabel 1. Distribusi Frekuensi Berdasarkan Karakteristik Umum Siswi kelas VII SMPN 26 Malang

\begin{tabular}{|c|c|c|}
\hline Usia(Tahun) & Frequensi & Persentase $(\%)$ \\
\hline 11 & 1 & 1,1 \\
\hline 12 & 57 & 63,3 \\
\hline 13 & 29 & 32,2 \\
\hline 14 & 2 & 2,2 \\
\hline 17 & 1 & 1,1 \\
\hline $\begin{array}{l}\text { Mendapatkan } \\
\text { Informasi }\end{array}$ & Frequensi & Persentase $(\%)$ \\
\hline Iya & 53 & 58,9 \\
\hline Tidak & 37 & 41,1 \\
\hline $\begin{array}{c}\text { Jumlah uang } \\
\text { saku (Rp) anak }\end{array}$ & Frequensi & Persentase(\%) \\
\hline 5000 & 3 & 3,3 \\
\hline $5000-10000$ & 60 & 66,7 \\
\hline $10000-15000$ & 27 & 30 \\
\hline $\begin{array}{l}\text { Pendapatan } \\
\text { keluarga } \\
\text { anak(Rp) }\end{array}$ & Frequensi & Persentase $(\%)$ \\
\hline$<2.5000 .000$ & 35 & 38,9 \\
\hline$>2.500 .000$ & 55 & 61,1 \\
\hline Konsumsi sayur & Frequensi & Persentase $(\%)$ \\
\hline Konsumsi & 34 & 37,8 \\
\hline $\begin{array}{c}\text { Tidak } \\
\text { konsumsi }\end{array}$ & 56 & 62,2 \\
\hline $\begin{array}{l}\text { Kepemilikan } \\
\text { media (buah) }\end{array}$ & Frequensi & Persentase $(\%)$ \\
\hline Satu & 19 & 21,1 \\
\hline Dua & 49 & 54,4 \\
\hline Tiga & 22 & 24,4 \\
\hline
\end{tabular}

Tabel 2 Distribusi Frekuensi Berdasar Usia Menarche

\begin{tabular}{ccc}
\hline $\begin{array}{c}\text { Usia } \\
\text { Menarche }\end{array}$ & Frequensi & Persentase(\%) \\
\hline 9 tahun & 4 & 6,3 \\
10 tahun & 14 & 22,2 \\
11 tahun & 22 & 34,9 \\
12 tahun & 20 & 31,7 \\
13 tahun & 3 & 4,8 \\
\hline Total & 63 & 100 \\
\hline
\end{tabular}


Tabel 3. Distribusi Frekuensi Berdasarkan Status menarche Pada Responden di SMPN 26 Malang

\begin{tabular}{lcc}
\hline $\begin{array}{l}\text { Status } \\
\text { menarche }\end{array}$ & Frequensi & Persentase(\%) \\
\hline $\begin{array}{l}\text { Menarche } \\
\begin{array}{l}\text { Belum } \\
\text { menarche }\end{array}\end{array}$ & 67 & 74,4 \\
\hline Total & 90 & 25,6 \\
\hline
\end{tabular}

Tabel 4. Distribusi Frekuensi Berdasarkan Konsumsi Junkfood Responden di SMPN 26 Malang

\begin{tabular}{ccc}
\hline $\begin{array}{c}\text { Konsumsi } \\
\text { Fastfood }\end{array}$ & Frequensi & Persentase $(\%)$ \\
\hline Rendah & 82 & 91,1 \\
Tinggi & 8 & 8,9 \\
\hline Total & 90 & 100 \\
\hline
\end{tabular}

Tabel 5. Distribusi Frekuensi Berdasarkan Paparan Media Porno Pada Responden di SMPN 26 Malang

\begin{tabular}{ccc}
\hline $\begin{array}{c}\text { Paparan } \\
\text { Media }\end{array}$ & Frequensi & Persentase(\%) \\
\hline Rendah & 80 & 88,9 \\
Tinggi & 10 & 11,1 \\
\hline Total & 90 & 100 \\
\hline
\end{tabular}

Berdasarkan Tabel 5 diketahui sebagian besar anak mengalami paparan media porno yang rendah, yakni 80 orang ( $88,9 \%)$.

Berdasarkan Tabel 6 diketahui bahwa responden yang mempunyai konsumsi junkfood rendah berdampak pada menarche sebanyak $68,8 \%$. Hasil uji statistic dengan menggunakan Fisher"s exact test didapatkan pvalue sebesar 0,416 yang artinya tidak ada hubungan antara konsumsi junkfood dengan status menarche pada responden SMPN 26 Malang.

Berdasarkan Tabel 7 diketahui bahwa responden yang mengalami paparan media porno rendah berdampak pada terjadinya menarche awal sebanyak $67,7 \%$. Hasil uji statistic dengan menggunakan Fisher"s exact test didapatkan pvalue sebesar 0,270 yang artinya tidak ada hubungan antara paparan media porno dengan status menarche pada responden SMPN 26 Malang.

Tabel 6. Tabulasi Silang Hubungan Konsumsi Fastfood dengan Status Menarche di SMPN 26 Malang

\begin{tabular}{lcccccc}
\hline Konsumsi Junkfood & \multicolumn{4}{c}{ Status Menarche } & Total & Pvalue \\
\cline { 2 - 5 } & \multicolumn{2}{c}{ Menarche } & \multicolumn{2}{c}{ Belum } \\
& \multicolumn{9}{c}{ Menarche } & & \\
\cline { 2 - 5 } & $\mathrm{f}$ & $\%$ & $\mathrm{f}$ & $\%$ & & \\
\hline Rendah & 62 & 68,8 & 20 & 22,2 & 82 & 0,416 \\
Tinggi & 5 & 5,5 & 3 & 3,3 & 8 & \\
Total & 67 & 74,3 & 23 & 25,5 & 90 & \\
\hline
\end{tabular}

Tabel 7. Tabulasi Silang Hubungan Paparan Media Porno dengan Status Menarche di SMPN 26 Malang

\begin{tabular}{|c|c|c|c|c|c|c|}
\hline \multirow{2}{*}{$\begin{array}{l}\text { Paparan Media } \\
\text { Porno }\end{array}$} & \multicolumn{4}{|c|}{ Status Menarche } & \multirow[t]{2}{*}{ Total } & \multirow[t]{2}{*}{ Pvalue } \\
\hline & \multicolumn{2}{|c|}{ Menarche } & \multicolumn{2}{|c|}{$\begin{array}{c}\text { Belum } \\
\text { Menarche }\end{array}$} & & \\
\hline & $\mathrm{f}$ & $\%$ & $\mathrm{f}$ & $\%$ & & \\
\hline Rendah & 61 & 67,7 & 19 & 21 & 80 & 0,270 \\
\hline Tinggi & 6 & 6,6 & 4 & 4,4 & 10 & \\
\hline Total & 67 & 74,3 & 23 & 25,4 & 90 & \\
\hline
\end{tabular}


paparan media tidak memberikan dampak langsung dengan terjadinya percepatan usia menarche. Secara teori disampaikan bahwa banyak faktor yang melatarbelakangi percepatan usia menarche menjadi lebih awal dibandingkan sebelumnya. Hasil penelitian Mutasya, F.U.,etc. (2016) menunjukkan bahwa faktor yang lebih dominan dalam mempengaruhi percepatan usia menarche adalah status gizi dan pendapatan perkapita keluarga. Hasil penelitian ini juga mendukung bahwa tidak terdapatnya hubungan antara bahwa paparan media tidak berkaitan dengan usia menarche.

Jika dikaji dari hasil penelitian ini lebih dapat dijelaskan bahwa percepatan usia menarche pada awal remaja putri lebih dikaitkan dengan segala sesuatu yang berkaitan langsung dengan pemenuhan gizi pada diri remaja putri. Untuk variabel yang diangkat oleh peneliti yakni konsumsi fastfood sebenarnya merupakan faktor yang secara lansung dapat mempengaruhi status gizi. Namun demikian didapatkan dari hasil penelitian ditemukan bahwa sebagian besar responden mengkonsumsi fastfood dalam kategori rendah. Hasil penelitian ini juga menjelaskan bahwa mayoritas pelajar kelas VII SMPN 26 Malang tidak mengkonsumsi makanan cepat saji dengan jumlah, frekuensi yang berlebih. Bahkan konsumsi fastfood responden termasuk kategori rendah sehingga jika di kaji masih belum menunjukkan keterkaitan atau berdampak pada percepatan usia menarche. Rendahnya konsumsi fastfood belum menjadikan perubahan secara patofisologis dan belum berdampak pada usia menarche. Faktor nutrisi yang meningkat dengan konsumsi fastfood yang berlebih tidak ditemukan dalam penelitian ini, sehingga tidak mempengaruhi pematangan seksual dan pertumbuhan remaja. Menurut Depkes yang terdapat dalam Penelitian Waryono (2010) diungkapkan bahwa menarche dipengaruhi oleh banyak hal yakni adanya perubahan hormone yang berdampak pada kematangan sel. Konsumsi makanan yang baik bahkan berlebih mampu mempercepat terbentuknya hormone yang dapat mengawali datangnya menarche.

Seperti diketahui bahwa makanan junkfood seringkali disebut dengan makanan sampah. Demikian juga dengan fastfood, mengandung lemak jenuh yang tinggi serta tinggi kandungan gulanya sehingga memiliki efek negative jika dikonsumsi oleh tubuh. Menurut Wulan (2008) disampaikan juga bahwa makanan dengan kandungan mikronutrien yang sedikit (serat, mineral, vtamin dan juga asam amino) dan juga mengandung kalori tinggi, gula serta lemak menjadi ciri dari makanan junkfood. Penambahan zat adiktif yang terdapat dalam makanan juga turut memberikan sumbangan efek negative bagi konsumen (Ashakiran, 2012) Efek negative ini diduga oleh penelitsi akan berpengaruh terhadap kesehatan tubuh jika dikonsumsi secara berlebihan dengan porsi dan frekuensi yang teratur. Hasil penelitian ini bertentangan dengan Penelitian Fitria (2018) yang menunjukkan bahwa ada hubungan antara asupan protein fast food, lemak fast food, dan frekuensi konsumsi fast food serta aktivitas fisik dengan usia menarche. Bertentangan pula dengan penelitian Surya Anita (2018) yang menunjukkan bahwa ada hubungan antara konsumsi makanan cepat saji dengan kejadian menarche dini $(p=0,021)$

Berbagai faktor yang mempengaruhi rendahnya konsumsi fastfood pada responden di SMPN 26 Malang salah satunya faktor umur. Sebagian besar responden kelas VII SMPN 26 Malang berusia 12 tahun. Usia 12 tahun merupakan usia dimulainya masa remaja seseorang dan berinteraksi dengan banyak orang. RI (2009) mengelompokkan masa remaja awal berada pada kisaran 12-16 tahun. Masa ini menjadi sebuah periode penting dalam rentang kehidupan seseorang, dimana terjadi perubahan dalam emosi. Krori (2011) menyampaikan bahwa perubahan remaja meliputi peran teman sebaya, kematangan dalam perilaku sosial, munculnya kelompok sosial yang baru, penetapan nilai baru dalam berteman dan lebih focus pada penerimaan sosial dirinya. 
Meningkatnya umur akan menurunkan konsumsi fasfood. Hasil penelitian ini tidak sesuai dengan Adriana (2007) yang mengungkapkan bahwa semakin kecil usia remaja, akan semakin menyukai fastfood. Sebagian besar responden berada diusia 12 tahun dengan kategori konsumsi fastfood yang rendah.

Banyaknya pengaruh lingkungan dan teman sebaya akan sangat menentukan penerimaan fast food (Adriana, 2007). Di lingkungan SMPN 26 Malang, responden mempunyai kecenderungan untuk sedikit mengkonsumsi fastfood. Pengaruh teman sebaya dalam mengkonsumsi makanan jenis tertentu tidak terlalu tampak di SMPN26 Malang. Opini peneliti ini didukung oleh data bahwa responden yang mengkonsumsi fastfood dengan kategori tinggi hanya sebagian kecil responden. Sehingga diduga tidak sampai mempengaruhi perilaku makan teman yang lain. Dimungkinkan adanya ketertarikan terhadap jenis makanan lain (yang bukan fastfood) yang menjadi kebiasaan dari keluarga masing-masing siswa. Hasil penelitian ini dikuatkan penelitian (Nusa,dkk. 2012; Afifah, LP., dkk. 2017) yang menyampaikan bahwa tidak ada hubungan antara teman sebaya dengan konsumsi fastfood.

Sosial ekonomi turut menentukan terpaparnya seseorang dengan konsumsi makanan cepat saji. Dalam penelitian ini sosial ekonomi responden yang tergambar dari penghasilan orangtua termasuk dalam kategori menengah yakni lebih dari 2,5jt per bulan. Hasil penelitian ini menunjukkan bahwa sebenarnya keluarga mempunyai kemampuan daya beli yang baik. Jika keluarga responden lebih fokus pada kebutuhan pangan, maka dimungkinkan keluarga akan memberikan uang saku yang lebih pada remaja untuk membeli makanan selama di sekolah, dan dimungkinkan pula remaja membeli fastfood. Namun demikian untuk prioritas produk yang dibeli tergantung dari keluarga masing-masing. Mahpolah, dkk (2008) yang menemukan kaitan antara penghasilan orangtua dengan konsumsi fastfood pada remaja SMA Kartika V-1 Balik Papan. Penelitian ini menunjukkan bahwa orangtua yang mempunyai penghasilan tinggi memberikan kecenderungan anak untuk mengkonsumsi fastfood. Bertentangan dengan hasil penelitian Afifah, LP., dkk. (2017) menunjukkan bahwa pendapatan orang tua tidak berhubungan dengan konsumsi fastfood pada remaja putri (pvalue 0,668). Hasil wawancara dengan para guru di SMPN 26 Malang, sebagai berikut

" Disini, banyak murid yang kekurangan makan. Jadi Kami guru disini berinisiatif untuk memberikan sebagian hasil sertifikasi guru untuk membantu murid-murid disini, dengan memberikan makanan pada mereka".

Hasil wawancara ini menunjukkan bahwa walau penghasilan orangtua diatas 2,5 juta namun diduga bahwa orientasi pengeluaran keuangan keluarga tidak terfokus pada pemenuhan asupan anak saja, namun pada hal hal yang lain yang mungkin dianggap lebih urgen oleh keluarga. Seperti halnya pendidikan, pakaian, ataupun kebutuhan lain diluar pangan. Jika dikaitkan dengan konsumsi fastfood, sudah dapat diartikan bahwa anakanak tidak mempunyai daya beli yang cukup untuk membeli makanan fastfood. Opini peneliti ini juga sesuai jika dikaitkan dengan jumlah uang saku yang diterima anak, yakni bahwa sebagian besar siswi mendapatkan uang saku Rp 5000-10000,Nominal tersebut dapat dikatakan kurang untuk membeli fastfood. Hasil penelitian ini sejalan dengan Penelitian Steyn, N. P., etc (2011) yang menemukan bahwa dari 3287 sampel yang diteliti dari berbagai etnis dan propinsi termasuk peserta di atas 16 tahun, diketahui bahwa frekuensi mengkonsumsi makanan cepat saji lebih dari $2 \mathrm{kali} / \mathrm{minggu}$ berkisar $15 \%$ di propinsi Barat laut hingga $14,7 \%$ di Gauteng. Asupan makanan anak jalanan tertinggi pada anak dengan kategori sosal ekonomi menengah. Sedangkan asupan makanan cepat saji tertinggi pada kategori sosial ekonomi tinggi yakni 13,2 $\%$.

Kondisi lingkungan yakni geografis wilayah turut mempengaruhi tinggi rendahnya konsumsi cepat saji responden. 
SMPN26 Malang terletak di kota Malang, namun demikian jika dikaji dari lingkungan SMPN 26 Malang khususnya kantin sekolah, dapat digambarkan bahwa makanan yang dijual tidak terdapat makanan cepat saji. Rendahnya konsumsi fastfood pada siswa, juga dimungkinkan ketidaktersediaan fastfood di kantin sekolah. Penelitian Monge-Rojas, R., Smith-Castro, V., Colón-Ramos, U., Aragón, M. C., \& Herrera-Raven (2013) terhadap 400 remaja (usia 12-17 tahun) menunjukkan bahwa remaja pedesaan mengkonsumsi makanan cepat saji 1,8 kali lebih sering dibandingkan dengan remaja perkotaan. Penelitian ini juga mengungkapkan bahwa remaja perdesaan mengklasifikasikan makanan cepat saji walaupun itu termasuk dalam makanan trandisional seperti keripik, salad, nasi, kacang hitam, dll. Demikian juga pada lokasi pembelian, jika pembelian makanannya di toko maka dianggap mengkonsumsi makanan cepat saji. Disimpulkan dalam penelitian ini tidak adanya kaitan antara konsumsi fastfood dengan usia menarche

Tidak ada hubungan antara paparan media porno dengan usia menarche pada responden SMPN 26 Malang. Seperti yang telah disampaikan di bahasan sebelumnya bahwa usia percepatan menarche lebih dipengaruhi oleh faktor status gizi dan pendapatan perkapita keluarga.

Dari hasil penelitian tampak bahwa sebagian besar responden yang mempunyai paparan rendah mengalami percepatan usia menarche sebanyak 67,7\%, namun demikian hasil tabulasi silang ini juga menunjukkan bahwa responden yang terpapar media porno kategori rendah juga belum mengalami menarche. Hasil penelitian ini menunjukkan bahwa paparan media porno bukan sebagai faktor yang mempengaruhi percepatan usia menarche, namun lebih dipengaruhi oleh faktor yang lebih mendominasi yakni seperti status gizi dan pendaatan perkapita keluarga.

Hasil ini didukung oleh Tity Wulandari, dkk (2018) yang menyatakan bahwa tidak ada hubungan yang significant antara usia saat menarche dengan paparan media audiovisual (pvalue $=0,68$ ), dan tidak ada juga hubungannya dengan faktor-faktor seperti status sosial ekonomi dan psikososial dengan usia saat menarche ( pvalue 0,64 dan 028 ) dan $\mathrm{p}$-value $=0,11$ (SEN, 2015). Hasil penelitian ini bertentangan dengan Kartono (2003) yang mengungkapkan bahwa film porno, blue film, dan segala tontonan yang walaupun tidak secara langsung tampak oleh mata siswi namun dari pesan yang ditampilkan akan menjadi rangsangan terbesar yang akan mematangkan dan mempercepat seksual anak. Brown (2005) mendukung pernyataan dari penelitian sebelumnya bahwa terpaparnya seseorang dengan media masa akan mempercepat pubertas, yang ditandai dengan terjadinya menarche. Senada pula dengan Orange (2005) bahwa materi media massa untuk orang dewasa lebih dapat membangkitkan hasrat seksual penontonnya dan Yazia (2019) yang menunjukkan adanya hubungan yang bermakna antara keterpaparan media massa internet dengan usia menarche $\mathrm{p}$ value $0,041 \quad(\mathrm{p} \leq 0,05)$. Yazia,V. (2019) menemukan sebagian besar $(51,1 \%)$ siswi SMPN22 Padang mempunyai keterpaparan media massa internet dalam kategori berat. Penelitian ini juga menemukan adanya hubungan keterpaparan media dengan usia menarche (pvalue 0,036).

Kemudahan remaja dalam menggunakan internet dengan media gadget/ komputer, menyebabnya berkembangnya kebiasaan buruk remaja yakni mengakses film seksual. Adanya media audiovisual dengan konten seksual mempercepat menarche remaja. Stimulus seksual dengan cara mengamati aktivitas seksual menyebabkan hipotalamus merangsng sekresi hormone, dan mempengaruhi proses kematangan organ reproduksi (Kartono, 2003). Darmonita (2011) mengemukakan bahwa rangasangan yang dialami remaja putri yang dilakukan secara terus menerus akan berpengaruh pada memorinya, yang kemudian akan merangsang kelenjar penghasil hormone seksual dan perkembangan seksual remaja. 
Dari uraian di atas dapat disampaikan bahwa tidak adanya kaitan antara konsumsi fastfood, paparan dengan media dikarenakan hasil temuan bahwa rendahnya konsumsi fastfood dan keterpaparan media pada remaja sehingga tidak menimbulkan efek yang berarti terhadap usia menarche.

\section{SIMPULAN}

Sebagian besar responden mengkonsumsi fastfood dalam kategori rendah yakni sebanyak 82 orang $(91,1 \%)$. Sebagian besar anak mengalami paparan media porno yang rendah, yakni 80 orang ( $88,9 \%$ ). Tidak ada hubungan antara konsumsi fastfood dengan status menarche pada responden SMPN 26 Malang (pvalue $=0,416$ ). Tidak ada hubungan antara paparan media porno dengan status menarche pada responden SMPN 26 Malang (pvalue $=0,270$ )

Perlunya menggali faktor determinan terjadinya percepatan usia menarche pada remaja putri, demikian juga keterlambatan usia menarche perlu dilakukan penelitian lanjutan.

\section{DAFTAR PUSTAKA}

A. Susanti, and S. Sunarto. 2012. "FAKTOR RISIKO KEJADIAN MENARCHE DINI PADA REMAJA DI SMP N 30 SEMARANG." Journal of Nutrition College, 1(1): 125-126,Oct 2012. https://doi.org/10.14710/jnc.v1i1.673.

Adriana, Deni. 2007. Anak Muda Dengan Semua Gaya Hidupnya. http://www.percikan-iman.com.

Afifah, LP., Suyatno., Aruben R., Kartini A. 2017. "Faktor-Faktor Yang Berhubungan Dengan Konsumsi Fast Food Pada Remaja Obesitas Di SMA Theresiana 1 Semarang Tahun 2017." JURNAL

KESEHATAN MASYARAKAT (e-Journal) $5(4$ Oktober).

http://ejournal3.undip.ac.id/index.php /jkm.

Archarya. 2009. "No TitleNutritional Status and Menarche in Adolescent Girls in an Urban Resettlement Colony of
South Delhi." Indian Journal of Community 31(4).

Ashakiran, Deepthi R. 2012. "Fast Foods and Their Impact on Health." $J$ Krishna Inst Med Sci Univ 1: 7-15. http://www.jkimsu.com/jkimsuvol1no2/jkimsu-vol1no2-RA-1-715.pdf.

Ayuningtyas R. 2013. "Hubungan Status Gizi Dengan Usia Menarche Pada Siswi SMP Negeri 1 Jember Dengan Usia Menarche.” 28. http://repository.unej.ac.id/bitstream/h andle/123456789/9993/Ratih

Ayuningtyas

062310101002_1.pdf?sequence $=1$.

Beddu S, Mukarramah S, Lestahulu V. 2015. "Hubungan Status Gizi Dan Usia Menarche Dengan Dismenore Primer Pada Remaja Puteri." The Southest Asian Journal of Midwifery 1(1): $16-21$. https://docplayer.info/57207943-

Hubungan-status-gizi-dan-usiamenarche-dengan-dismenore-primerpada-remaja-putri.html.

Brown, E. 2005. Nutrition. Through the Life CycleSecond Edition.: Thomson Wadsworth. USA.

Darmonita, Pirmita. 2011. Faktor-Faktor Yang Berhuungan Dengan Usia Menarche.

Ekerbicer HC, Celik M, Kiran H, Kiran G. 2007. . ". Age at Menarch in Turkish Adolescents in Kahramanmaras: Eastern Mediterranian Region of Turkey." . Eur J Contracept Reprod Health Care 12: 289-93. https://www.ncbi.nlm.nih.gov/pubme d/17763268.

Fitria. 2018. "Hubungan Konsumsi Fast Food Dan Aktivitas Fisik Dengan Usia Menarche Pada Siswi Mtsn Model Padang Dan Smpn 16 Model Padang Tahun 2018." http://eresources.perpusnas.go.id:2083/login. aspx?direct $=$ true $\& \mathrm{db}=$ edsoai $\& A N=$ ed soai.on $1117572663 \&$ site $=$ eds-live.

Golub MS, Collman GW, Foster PM, Kimmel CA, Rajpert-De Meyts E, Reiter EO, et al. 2008. "No 
TitlePublic Health Implications of Altered Puberty Timing." Pediatrics. 121: 218-30. https://www.ncbi.nlm.nih.gov/pubme d/18245514.

Indriyastuti HI. 2013. Hubungan Riwayat Menonton Audio Visual Dengan Usia Menarche Pada Siswi SMP Di Kecamatan Kebumen Kabupaten Kebumen. [Yogyakarta]: Universitas Gadjah Mada. http://etd.repository.ugm.ac.id/index. php?mod=penelitian_detail\&sub=Pen elitianDetail \&act $=$ view $\&$ typ $=h t m l \& b$ uku_id=63864.

JW, Santrock. 2003. Adolesence. Jakarta: Erlangga.

Kaplowitz, P.B. 2008. 121 Paediatric Link Beetwen Body Fat and the Timing of Pubertas.

Karapanou O, Papadimitriou A. 2010. "Determinants of Menarche." Reprod Biol Endocrinol 8: 115. https://rbej.biomedcentral.com/article s/10.1186/1477-7827-8-115.

Kartono, K. 2003. Patologi Sosial. Jakarta: Raja Grafindo Persada.

Krori. 2011. "Developmental Psychology." Homeopathic Journal 4(3). http://www.homeorizon.com/homeop athicarticles/ psychology/developmentalpsychology.

Mahpolah, Mahdalena Mahdalena, Vita Purnamasari. 2008. "Faktor - Faktor Yang Berhubungan Dengan Dengan Kebiasaan Mengkonsumsi Fast Food Pada Remaja SMA Kartika V-1 Balikpapan." Nutrition Mayor of Health Polytechnic Banjarmasin 16(3).

http://academicjournal.yarsi.ac.id/inde x.php/jurnal-fk-yarsi/article/view/249.

Monge-Rojas, R., Smith-Castro, V., ColónRamos, U., Aragón, M. C., \& Herrera-Raven, F. 2013. "Psychosocial Factors Influencing the Frequency of Fast-Food Consumption among Urban and Rural Costa Rican Adolescents." Nutrition 29(7-8): 1007-12. resources.perpusnas.go.id:2182/10.10 16/j.nut.2013.01.021.

Morris, D.H., Jones, M.E., Schoemaker, M.J., Ashworth, A., Swerdlow, A.J. 2010. "Determinants of Age at Menarche in The UK: Analyses from the Breakthrough Generations Study." British Journal Cancer 103(11): 1760-64.

https://www.ncbi.nlm.nih.gov/pubme $\mathrm{d} / 21045834$.

Mutasya, F.U., Edison, Hasyim, H. 2016. "Faktor-Faktor Yang Berhubungan Dengan Usia Menarche Siswi SMP Adabiah." Jurnal Kesehatan Andalas. 5(1).

http://jurnal.fk.unand.ac.id/index.php/ $\mathrm{jka} /$ article/view/475.

Nelson WE. 1999. Ilmu Kesehatan Anak Nelson. Jakarta: EGC.

Nusa, Adisti Fitriana Andar, Annis Catur Adi. 2012. "Hubungan Faktor Perilaku, Frekuensi Konsumsi Fast Food, Diet Dan Genetik Dengan Tingkat Kelebihan Berat Badan." Media Gizi ildonesia 9(1). http://journal.unair.ac.id/filerPDF/mgi f4cfed1d44full.pdf.

Orange, Teresa. 2005. The Media Diet For Kids. Jakarta: PT. Serambi Ilmu Semesta.

Pulungan AB. 2010. Buku Ajar Endokrinologi Anak. 1st Ed. ed. editors In: Batubara Jose RL, AAP Tridjaja B, Pulungan AB. Jakarta: Badan Penerbit IDAI.

Purba FS, Sarumpaet SM, Jemadi. 2013. "Faktor-Faktor Yang Berhubungan Dengan Dismenore Pada Siswi SMK Negeri 10 Medan Tahun 2013." Jurnal Gizi, Kesehatan Reproduksi dan Epidemiologi. 2(5). https://jurnal.usu.ac.id/index.php/gkre /article/view/4060.

RI, Departemen Kesehatan. 2009. Kategori Usia.

S., Sastrawinata. 2009. Wanita Dalam Berbagai Masa Kehidupan. Dalam: Ilmu Kandungan. Jakarta: yayasan Bina Pustaka Sarwono Prawihardjo.

Schuh, S. M., Kadie, J., Rosen, M. P., 
Sternfeld, B., Reijo Pera, R. A., \& Cedars, M. I. 2019. "Links between Age at Menarche, Antral Follicle Count, and Body Mass Index in African American and European American Women. Fertility and Sterility." Fertility and Sterility 111(1): $\quad 122-31 . \quad$ https://eresources.perpusnas.go.id:2182/10.10 16/j.fertnstert.2018.09.007.

SEN, Sinaga. 2015. "Faktor-Faktor Yang Berhubungan Dengan Status Menarche Di SMP X Rangkasbitung." COPING Ners $J$ 3: 34-43.

https://ojs.unud.ac.id/index.php/copin g/article/view/15683.

Steyn, N. P., Labadarios, D., \& Nel, J. H. 2011. "Factors Which Influence the Consumption of Street Foods and Fast Foods in South Africa--a National Survey." Nutrition Journal 10(104). https://eresources.perpusnas.go.id:2182/10.11 86/1475-2891-10-104.

Surya Anita, Yunida Turisna Simanjuntak. 2018. "The Correlation between Junk Food Consumption and Age of Menarche of Elementary School Student In Gedung Johor Medan." Unnes Journal of Public Health 1: 21. https://e-

resources.perpusnas.go.id:2182/10.15 294/ujph.v7i1.17093.

Tity Wulandari, Melda Deliana, Sri Sofyani, \& Siska Mayasari Lubis. 2018. "Relationship between Age at Menarche and Exposure to Sexual Content in Audio-Visual Media and Other Factors in Islamic Junior High School Girls." Paediatrica Indonesiana 6(323). https://eresources.perpusnas.go.id:2182/10.14 238/pi57.6.2017.323-8.

Waryono. 2010. Gizi Reproduksi. jakarta: Pustaka Rihama.

Wulan, Reni Sari. 2008. Dangerous Junk Food. O2: Yogyakarta.

WULANSARI, NIKEN ARYANI. 2012. Hubungan Konsumsi Junk Fod Dan Media Informasi Terhadap Menarche
Dini Pada Siswi Sekolah Dasar Di Surakarta.

http://eprints.ums.ac.id/20562/.

Yazia, Y. 2019. "HUBUNGAN KETERPAPARAN MEDIA MASSA INTERNET DAN STATUS GIZI TERHADAP USIA MENARCHE PADA SISWI KELAS VII SMPN 22 PADANG." Jurnal Penelitian dan kajian Ilmiah MENARA ILMU Univeristas Muhammadiya Sumatera Barat, 13(6). https://jurnal.umsb.ac.id/index.php/m enarailmu/article/view/1421.

Zhang, Z., Hu, X., Yang, C., \& Chen, X. 2019. "Early Age at Menarche Is Associated with Insulin Resistance: A Systemic Review and MetaAnalysis." Postgraduate Medicine 131(2): 144-50. https://eresources.perpusnas.go.id:2182/10.10 80/00325481.2019.1559429. 